\title{
FLEKSIBILITAS DAN AKSESIBILITAS DIGITALISASI PEMBELAJARAN BAHASA DAN SASTRA INDONESIA DI MASA PANDEMI COVID-19
}

\author{
Dina Zahrotun Ni'mah' ${ }^{1}$, Evi Chamalah ${ }^{2}$, Aida Azizah ${ }^{3}$ \\ Pendidikan Bahasa dan Sastra Indonesia, Fakultas Keguruan dan Ilmu Pendidikan, \\ Universitas Islam Sultan Agung, Semarang, Indonesia \\ e-mail:dinazahrotunnikmah@gmail.com ${ }^{1}$,chamalah@unissula.ac.id ${ }^{2}$, aidaazizah@unissula.ac.id ${ }^{3}$
}

\begin{abstract}
ABSTRAK
Pandemi Covid-19 telah banyak mengubah banyak aspek terutama dibidang pendidikan, hal tersebut membuat sistem pembelajaran juga harus bisa menyesuaikan. Penelitian ini bertujuan untuk mengetahui proses digitalisasi dalam pembelajaran Bahasa dan Sastra Indonesia serta manfaatnya. Kemudian perlu juga diketahui tentang Aksesibilitas dan Fleksibilitas pembelajaran dengan digitalisasi. Metode yang digunakan dalam penelitian ini ialah deskriptif kualitatif dengan menguraikan dan menjabarkan sesuatu menggunakan kalimat dalam keadaan yang jelas terhadap objek yang diteliti. Digitalisasi menjadi salah satu alternatif metode pembelajaran yang terdapat kelebihan dan kekurangan di dalamnya. Pembelajaran Bahasa dan Sastra Indonesia saat ini juga menggunakan digitalisasi terutama dalam praktik sebagai sarana media pembelajaran dengan menggunakan beberapa aplikasi digital seperti YouTube, Zoom, Google Meet, Google Clasroom, media sosial, dan lain sebagainya. Sehingga di masa pandemi Covid-19 digitalisasi cukup fleksibel untuk diterapkan karena bisa menyesuaikan dengan kebutuhan dari elemen pendidikan, menjadi sarana untuk memenuhi tujuan pembelajaran, dan meтиdahkan proses pembelajaran. Tetapi di sisi lain tidak semиa elemen pendidikan dapat dengan mudah mengakses sistem pembelajaran dengan digitalisasi baik dari segi faktor ekonomi maupun teknologi.
\end{abstract}

Kata kunci: Pandemi Covid-19, Pembelajaran, Digitalisasi, Fleksibilitas, Aksesibilitas.

\begin{abstract}
The Covid-19 pandemic has changed many aspects, especially in the field of education, it makes the learning system must also be able to adjust. This research aims to find out the digitization process in the learning of Indonesian Language and Literature and its benefits. Then it is also necessary to know about accessibility and flexibility of learning with digitalization. The method used in this study is qualitative descriptive by deciphering and describing something using sentences in a clear state against the object studied. Digitalization becomes one of the alternative learning methods that have advantages and disadvantages in it. Indonesian Language and Literature Learning currently also uses digitalization especially in practice as a means of learning media by using several digital applications such as YouTube, Zoom, Google Meet, Google Clasroom, social media, and so on. So that in the Covid-19 pandemic digitalization is flexible enough to be applied because it can adjust to the needs of the educational element, become a means to meet learning goals, and facilitate the learning process. But on the other hand, not all elements of education can easily access the learning system by digitization both in terms of economic and technological factors.
\end{abstract}

Keywords: Covid-19 Pandemic, Learning, Digitization, Flexibility, Accessibility.

\section{PENDAHULUAN}

Kasus pertama Covid-19 dilaporkan muncul di Wuhan, Provinsi Hubei, Cina. Virus ini sangat berbahaya dan penyebarannya sangat cepat. Sejak awal kemunculannya sampai sekarang telah berdampak pada banyak aspek kehidupan terutama di bidang pendidikan. Semenjak kebijakan pemerintah untuk meminimalisir penyebaran virus Covid-19 dengan melakukan segala aktivitas dari rumah diterapkan, pembelajaran yang dulunya bisa dilakukan dengan bertatap muka sekarang menjadi lebih berjarak karena tidak bisa bertemu secara langsung.

Adanya kecanggihan teknologi cukup banyak membantu sistem pembelajaran di masa 
pandemi karena tetap dapat dilakukan kapan saja dan dimana saja. Salah satu hal yang berkaitan erat dengan teknologi ialah adanya media sosial yang bisa membuat jarak terasa dekat dan memudahkan mendapat informasi sehingga saat ini proses digitalisasi penting sebagai alternatif media pembelajaran. Dengan digitalisasi merupakan upaya untuk dapat melakukan pembelajaran yang melibatkan proses interaksi audio, visual, gambar, dan sebagainya. [1] Menurut Sukmana (2005) Digitalisasi memerlukan peralatan seperti komputer, scanner, operator media sumber dan software pendukung. Namun tidak setiap siswa memiliki peralatan yang mendukung atau memadai untuk melakukan proses digitalisasi.

Pembelajaran Bahasa dan Sastra Indonesia dimasa pandemi Covid-19 lebih banyak menggunakan metode e-learning baik dalam proses belajar mengajar atau untuk pembelajaran teori maupun praktik. [2] E-learning merupakan sebuah proses pembelajaran yang dilakukan melalui network (jaringan komputer, biasanya lewat internet atau intranet. Pembelajaran teori bukan hanya sekadar membagikan informasi kepada mahasiswa tetapi lebih lanjut mahasiswa juga harus memahami tentang informasi apa yang di berikan oleh dosen. Kemudian dalam pembelajaran praktik, harus bisa menerapkan dengan tepat ilmu yang sudah didapatkan. Untuk memudahkan melakukan praktik diperlukan proses digitalisasi. Dan dengan digitalisasi membuat adanya interaksi antara dosen dan mahasiswa, jika tidak memahami materi atau pembahasan yang diberikan, dapat mengajukan pertanyaan kepada dosen dan bisa dijelaskan secara virtual melalui media digital.

Ada banyak jenis digital yang dapat digunakan sebagai media pembelajaran, seperti web site, media sosial, gambar dan video digital, serta audio digital. Hampir semua jenis tersebut sering digunakan dalam proses pembelajaran terlebih dimasa pandemi ini. [3] Menurut Bekti (2015: 35), web site merupakan kumpulan halaman-halaman yang digunakan untuk menampilkan informasi teks, gambar diam atau gerak, animasi, suara, dan atau gabungan dari semuanya, baik yang bersifat statis atau dinamis yang membentuk satu rangkaian bangunan yang saling terkait, yang masing-masing dihubungkan dengan jaringan-jaringan halaman. Web site menyajikan topik dalam bentuk halaman yang dapat berisi berkas yang bervariasi. Lalu ada media sosial yang merupakan sarana prasarana untuk menjalin komunikasi atau membagikan informasi. [4] Mayfield dari I Crossing berpendapat bahwa media sosial merupakan media atau sarana dimana user (pengguna) dapat membuat konten dan aplikasi serta memungkinkan user tersebut untuk berinteraksi dengan bertukar wawasan dengan user lain. Jenis media sosaial cukup beragam, seperti WhatsApp yaitu aplikasi yang digunakan agar bisa terhubung dan berkomunikasi dengan pengguna lain, Line yang memiliki fitur dan fungsi yang sama dengan WhatsApp yang menyediakan fitur obrolan baik antar orang maupun dalam grup, pengiriman pesan suara, panggilan telepon, video, dan sebagainya, kemudian ada Instagram yang menghadirkan objek video atau gambar, pesan, panggilan suara, maupun panggilan video. YouTube merupakan media yang banyak digunakan dalam proses pembelajaran karena memungkinkan untuk mengunggah video yang memiliki durasi lama dan proses pengunggahan materi pembelajaran cukup mudah serta video yang disajikan dapat di unduh untuk ditonton lagi di lain waktu, dan masih banyak aplikasi media sosial lainnya. Untuk gambar dan video digital biasanya dibuat untuk mempermudah menjelaskan materi 
yang kemudian akan dikirimkan lewat media sosial atau sebagai bukti adanya pembelajaran yang dilakukan. Audio digital digunakan agar penyampaian materi atau informasi perlu adanya bahasa secara lisan untuk melatih kemampuan berbicara dan menyampaikan pendapat, pengolahan audio digital lebih lanjut juga perlu adanya Web site dan media sosial.

Meskipun media digital menawarkan banyak kelebihan, tetapi tidak semua mahasiswa memiliki kemudahan dalam mengakses media digital, karena beberapa faktor seperti tingkat ekonomi yang berbeda, kemudahan jaringan, dan kualitas pemahaman. Digitalisasi pembelajaran juga menjadi alternatif yang cukup fleksibel karena bisa dilakukan kapan saja dan dimana saja, namun apakah kegiatan pembelajaran akan menjadi efektif bagi mahasiswa. Maka peneliti memilih Judul "Fleksibilitas dan Aksebilitas Digitalisasi Pembelajaran Bahasa dan Sastra Indonesa di Masa Pandemi Covid-19" agar dilakukan penelitian ini untuk mengetahui kemudahan tingkat fleksibilitas dan akses pembelajaran bahasa dan sastra Indonesia dengan digitalisasi pembelajaran. Selain itu untuk mengetahui manfaat dan kendala apa saja yang dialami oleh mahasiswa dalam melakukan digitalisasi pembelajaran Bahasa dan Sastra Indonesia.

[5] Pembelajaran merupakan proses yang melibatkan modifikasi relatif stabil dalam hubungan dengan stimulus-respons yang dikembangkan sebagai konsekuensi dari interaksi lingkungan fungsional melalui indra (Lachman, 1997). Sehingga pada masa pandemi Covid- 19 pembelajaran menyesuaikan atau dimodifikasi sedemikian rupa menyesuaikan situasi, kondisi dan tidak mengesampingkan tujuan dari pembelajaran itu sendiri. Pembelajaran dilakukan dengan e-learning yang tentunya memerlukan penyesuaian dari keadaan sebelumnya dan bergantung pada jaringan yang ada.

Menurut kamus besar bahasa Indonesia, digitalisasi merupakan proses pemberian atau pemakaian sistem digital. [6] Menurut Wuryanta (2017) teknologi digital mampu menggabung, menyajikan, atau mengkonversi suatu informasi, memanipulasi, dengan cara cropping informasi asli, baik itu mengurangi atau menambah informasi tersebut. Adanya sistem digital dapat dimanfaatkan sebagai media pembelajaran di masa pandemi Covid-19 yang sebelumnya cukup mengguncang masyarakat terutama dalam bidang pendidikan. [7] Menurut Purdy dan Wright (1992) menyatakan bahwa terdapat pergeseran dan perbedaan paradigma pola pembelajaran antara pembelajaran yang tidak melibatkan teknologi dengan pembelajaran yang menggunakan teknologi dan antara konsep pembelajaran di kelas dengan pembelajaran terbuka atau pembelajaran digital yang tidak harus menjalankan pembelajaran di kelas.

Berdasarkan artikel rujukan yang dibuat oleh [8] Deddy Kurniawan berjudul "Pembelajaran Bahasa Jerman Di Kala Pandemi. Covid-19 Fleksibilitas dan Aksesibilitas" berfokus pada pembelajaran Bahasa Jerman di masa pandemi Covid-19 saat melanda Indonesia. Artikel tersebut membahas Permasalahan dan upaya-upaya penyelesaiannya dalam pembelajaran yang terjadi saat pandemi Covid-19 melanda di Indonesia. Pembahasan mengenai kesulitan belajar ketika pandemi Covid-19 antara lain karena Intrapersonal, Sosial Ekonomi Keluarga, Penguasaan TI dan Kondisi Infrastruktur, Tugas Belajar Kolaboratif. Lalu upaya yang dipaparkan juga menyangkut penyelesaian dari kesulitan yang dihadapi sehingga harapannya tingkat fleksibilitas dan aksesibilitas yang baik dapat menyebar di daerah mana pun. 
Sedangkan pada artikel yang saya buat berfokus pada tingkat fleksibilitas dan aksesibilitas dari digitalisasi pembelajaran Bahasa Indonesia di masa pandemi Covid-19. Memaparkan faktor apa saja yang mempengaruhi digitalisasi pembelajaran Bahasa dan Sastra Indonesia di masa Pandemi Covid-19 sehingga mengetahui tingkat fleksibel dan mudah di akses atau tidakkah pembelajaran berbasis digitalisasi tersebut dilakukan oleh mahasiswa. Selain itu pada artikel ini juga memaparkan apa saja hal-hal yang membuat digitalisasi pembelajaran menjadi fleksibel di masa pandemi Covid-19. Dan juga membahas kesulitan apa saja dan penyelesaian kendala aksesibilitas dalam pembelajaran Bahasa Indonesia di masa pandemi Covid-19. Sehingga dapat membantu dalam menciptakan pembelajaran Bahasa Indonesia yang fleksibel dan mudah di akses di masa Pandemi Covid-19.

\section{METODOLOGI PENELITIAN}

Metode yang digunakan dalam penelitian ini adalah metode deskriptif kualitatif. [9] Metode Deskriptif menurut Surakhmad (1985:147) merupakan metode yang membicarakan kemungkinan untuk memecahkan masalah aktual, dengan jalan mengumpulkan data, menyusun, mengklarifikasi lainnya, menganalisis, dan menginterpretasikannya. Maka, metode deskriptif berisi penjelasan dari hasil penelitian yang telah didapat. [10] Kemudian Metode penelitian kualitatif adalah metode yang berdasarkan pada postpotivisme, sedangkan untuk meneliti objek alamiah, di mana peneliti sebagai instrumen kunci, teknik pengumpulan data dilakukan dengan cara triangulasi (gabungan). Pada metode kualitatif menekan pada mutu sebuah penelitian yang dilakukan, bukan berdasarkan nilai secara angka yang dituliskan.

Sehingga dalam penelitian ini berfokus pada penelitian mengenai tingkat fleksibel dan kemudahan atau kesulitan akses dalam pembelajaran bahasa dan sastra Indonesia dengan melakukan digitalisasi yang di lakukan dengan cara merumuskan masalah, mengumpulkan data terkait permasalahan, menyusun data yang telah didapatkan, melakukan analisis, membuat penyelesaian masalah, dan melakukan interpretasi. Proses yang dilakukan dengan mendeskripsikan atau menjelaskan setiap permasalahan dan penyelesaian menggunakan susunan kalimat. Data penelitian didapatan dengan teknik membuat angket yang berisi beberapa pertanyaan terkait artikel yang akan dibuat dan melakukan survei kepada objek dengan mengisi kuisioner melalui google form. Tautan dibagikan kepada mahasiswa yang menjadi objek peneitian, melalui Whatss App yang kemudian mahasiswa diminta untuk mengakses tautan tersebut dan mengisi pertanyaan yang ada sesuai situasi dan kondisi yang dialami.

\section{HASIL DAN PEMBAHASAN}

Dari penelitian yang telah dilakukan oleh penulis terhadap 25 orang mahasiswa semester empat terkait fleksibilitas dan aksesibilitas digitalisasi pembelajaran bahasa dan sastra Indonesia di masa pandemi covid-19, didapatkan bahwa ada satu mahasiswa yang belum mengetahui arti dari digitalisasi pembelajaran, ada yang mengartikan digitalisasi pembelajaran secara sempit sebagai proses mengaplikasikan pembelajaran dengan media digital. Secara luas diartikan kegiatan belajar mengajar yang diaksanakan dengan mengalihkan media dari yang sebelumnya di ajarkan secara langsung dari dosen ke mahasiswa, beralih mengggunakan media digital baik dari bentuk media grafik, audio, visual, dan sebaginya yang didukung kecanggihan teknologi seperti menggunakan aplikasi maupun website pembelajaran. Sedangkan beberapa ada juga yang mengartikan digitalisasi pembelajran sebagai peralihan metode belajar konvensional ke metode digital dengan harapan sebagai upaya pengembangan dalam memudahkan dan mengakses pembelajaran.

Terkait fleksibilitas, diartikan sebagai keleluasaan pembelajarn yang dapat diakses kapan dan dimana saja. Lebih lengkapnya fleksibilitas pembelajaran merupakan penyesuaian atau 
adaptasi pembelajaran dengan berbagai situasi dan kondisi, penyesuaian bukan hanya dari cara penyampaian materi saja, tetapi seluruh komponen pendidikan dapat menyesuaikan, termasuk jenis, media, strategi, metode/model yang digunakan sehingga dapat menimbulkan pembelajaran yang efektif dan nyaman bagi seluruh komponen pendidikan yang terlibat dalam pembelajaran itu sendiri. Namun, ada dua mahasiswa yang tidak mengetahui ataupun memahami definisi dari fleksibilitas pembelajaran.

Dari penelitian yang dilakukan masih terdapat dua mahasiswa yang belum mengetahui definisi dari aksesibilitas pembelajaran itu sendiri. Selebihnya, dari 23 mahasiswa banyak yang mengartikan bahwa aksesibilitas merupakan kemudahan dalam mengakses pembelajaran. Lebih rincinya, aksesibilitas pembelajaran dalam hal ini ialah akses yang dapat dijangkau oleh mahasiswa untuk melakukan aktivitas pembelajaran sehingga lebih efisien.

Tentu dalam digitalisasi pembelajaran diperlukan fleksibilitas dan aksesibilitas yang baik bagi mahasiswa terlebih untuk pembelajaran bahasa dan sastra Indonesia terutama di masa pandemi covid-19 seperti sekarang ini. Tidak semua proses digitalisasi pembelajaran yang dilakukan oleh mahasiswa berjalan dengan fleksibel dan adanya kemudahan akses. Dari data penelitian yang diperoleh, dua mahasiswa yang menjawab tidak tau bahaimana fleksibikitas pembelajaran yang mereka alami. tiga mahasiswa menjawab tidak fleksibel dengan alasan sulit memahami materi secara autodidak, gagap teknologi atau sulit menggunakan teknologi, dan kerepotan dalam melakukan praktikum. Enam mahasiswa menjawab cukup fleksibel karena pembelajaran dapat diakses dimanapun dan kapanpun, dosen memberikan jangka waktu yang lama untuk penugasan tetapi ada juga yang memberikan jangka waktu singkat, selebihnya mahasiswa menjawab pembelajaran digital fleksibel diakibatkan dapat diakses hanya melalui gawai saja, lebih mengefisiensi runag dan waktu, pembelajaran terjadwal dengan baik, dan menimbulkan sikap kemandirian dalam belajar.

Kemudahan aksesibiltas juga tidak dirasakan oleh selurauh mahasiswa, dua mahasiswa tidak mengetahui bahaimana akses pembelajaran yang mereka rasakan. Dari data yang didapatkan peneliti, ada tujuh orang mahasiswa yang tidak mengalami kemudahan aksesibilitas dikarenakan sulit mendapatkan jaringan di daerahnya, peralatan yang dimiliki kurang mendukung untuk mendapatkan akses pembelajaran. Enam mahasiswa merasa aksesibilitas pembelajaran cukup mudah karena mendapatkan sosialisasi terkait digitalisasi pembelajaran, mendapatkan akses yang baik di wilayahnya, tersedia alat dan fitur yang memadahi. Mahasiswa yang lain menjawab aksesibilitas yang dirasakan mudah karena sistem tidak ribet, setiap universitas memiliki web site tersendiri untuk mengakses pembelajaran, dapat mengakses pembelajaran dari berbagai sumber ajar, paham tentang penggunakan teknologi, merasa lebih praktis dan efisien.

Dibalik pro dan kontra mengenai tingkat fleksibilitas dan aksesibilitas yang dialami masing-masing mahasiswa, ada juga keunggulan yang mereka rasakan dari adanya digitalisasi pembelajaran itu sendiri, diantaranya tidak mudah merasa bosan dnegan pembelajaran, lebih nyaman ketika mengerjakan tugas, biaya terjangkau karena tidak perlu adanya biaya sewa kos, transportasi, dan sebagainya, wawasan lebih luas dikarenakan bisa mencari banyak referensi, dapat menambah pengalaman belajar dengan memeroleh beragam informasi, dapat mahir teknologi, dapat mengutamakan pembelajaran tetapi bisa bersamaan melakukan aktivitas lain baik aktivitas rumah maupun organisasi.

Kelemahan dalam melakukan digitalisasi pembelajaran yang dialami mahasiswa diantaranya ada beberapa materi yang suit dipahami, untuk kegiatan praktikum tidak bisa dilakukan dengan baik dan benar karena tidak dapat dilakukan secara langsung, kurangnya interaksi dengan dosen serta minimnya pengawasan yang dilakukan, kurangnya kedisiplinan atau kesadaran mahasiswa, memengaruhi kesehatan seperti kesehatan mata karena terlalu banyak menatap layar gawai ataupun laptop, dan sejenisnya, mahasiswa merasa jenuh dan bosan.

Dibalik kesulitan yang dirasakan, tentu ada hal yang dapat dijadikan sebagai akternatif pemecahan masalah tersebut, atau solusi yang dapat dilakukan, yaitu mahasiswa harus punya inisiatif atau kesadaran diri untuk berani mencoba hal baru, dan menjadi produktif dalam berkegiatan untuk mendaatkan suatu manfaat baik dirinya sendiri maupun bagi orang lain. Jika mahasiswa mengalami kesulitan dalam pemahaman belajar, maka menyimak secara saksama dan 
teliti apa yang disampaikan oleh dosen dan jika masih belum paham, bisa menanyakan kejelasanya. Terkait dengan kesehatan terutama pada mata, mahasiswa dapat menggunakan kacamata anti radiasi dan memperbnyak asupan vitamin A yang bermanfaat menjaga kesehatan mata. Melatih mahasiswa guna kesiapan digitalisais pembelajaran dengan sosialisasi, pengarahan, dan latihan menggunakan teknologi. Lebih aktif baik dalam mencari sumber belajar dan menjalin komunikasi dengan dosen ketika pembelajaran. Ketika pembelajaran dimulai, fokus terhadap apa yang disampaikan, tidak ditinggal memainkan media sosial atau aplikasi lain yang mengganggu fokus. Dosen menyiapkan pembelajaran yang menarik dan dapat diterima olah mahasiswa agar tidak cepat merasa bosan, menyediakan media, metode, dan stratergi yang beragam dalam pembelajaran. Terkait kesulitan jaringan dan akses, dapat diatasi dengan mencari lokasi terdekat yang terdapat jaringan lebih kuat namun tetap dengan mematuhi protokol kesehatan jika memilih pergi keluar rumah agar mencegah terpapar virus covid-19. Jika memilih untuk tidak keluar rumah, maka pastikan menggunakan kartu sim yang memiliki jaringan terbagus diwilayah tersebut. Jika fasilitas kurang memadahi, bisa meminta bantuan teman terdekat rumah untuk menghubungi apabila ada informasi penting terkait pembelajaran. Kurang lebih itu solusi yang dapat diupayakan mahasiswa dan dosen, pemerintah diharapkan dapat memberikan akses jaringan secara merata di seluruh wilayah dan subsidi kuota yang diberikan dapat merata agar dapat digunakan secara maksimal.

Ada beragam dampak yang dirasakan mahasiswa ketika melakukan digitalisasi pembelajaran terlebih di masa pandemi covid-19 seperti sekarang, mulai dari sampai positif maupun negatif. Dampak positifnyamahassiwa meraskan pengalaman memanfaatkan kecanggihan teknologi yang ada dan merasakan kemudahan dan keleluasaan melakukan pembelajaran. Namun, dampak negatifnya, mahasiswa merasa lebih pasif karena kurangnya melakukan interaksi dan ketidakleluasaan melakukan aktivitas di luar rumah.

Terkait keefektifan dan keefisiensian digitalisasi pembelajaran bahasa dan sasrta Indonesia di masa pandemi covid-19 ini sepuluh mahasiswa merasa bahwa pembelajarannya tidak efektif dikarenakan setelah mahasiswa melakukan presensi di web site universitas, mereka kemudian tidak aktif melakukan komunikasi mengenai materi bahasa dan sastra Indonesia yang baru saja didapatkan. Mahasiswa cenderung hanya peduli terhadap daftar hadir dibandingkan kewajibannya dalam memahami materi bahasa dan sastra Indonesia. Tiga mahasiswa menjawab cukup efektif karena dengan digitaisasi pemberian materi bahasa dan sastra Indonesia masih bisa dijagkau oleh mahasiswa. Selebihnya menjawab efektif dan efisien apalagi untuk diterapkan di masa pandemi seperti saat ini. Buktinya dengan digitalisai pembelajaran, kegiatan pembelajaran teori maupun praktik bahasa dan sastra Indonesia masih bisa dilakukan, mislanya saja Dosen memberikan materi melalui web kampus kemudian didiskusikan menggunakan aplikasi zoom, mahasiswa aktif bertanya dan melakukan komunikasi, hasil dari belahar teori ialah mahasiswa melakukan praktik dari materi yang telah disampaikan dengan mengunggah ke YouTube, media sosial, atau media pembelajaran lain, dan dosen melakukan evaluasi serta penilaian.

\section{SIMPULAN}

Dari hasil penelitian yang telah dilakukan, dapat disimpulkan bahwa tidak semua mahasiswa mengetahui pengertian dari dari digitalisasi pembelajaran, fleksibilitas dan aksesibilitas pembelajaran itu sendiri. Ada mahasiswa yang tidak mengetahui bagaimana hal yang dirasakan terkait kemudahan akses ataupun tingkat fleksibilitas pembelajaran digital, terdpat yang mengalami kesulitan akses dan merasa pembelajaran digital tidak fleksibel, tetapi sebagian besar sudah mendapatkan kemudahan akses serta merasa pembelajaran digital fleksibel karena dapat dilakukan dengan gawai dan diakses kapan serta dimana saja. Dibalik beragam kelemahan digitalisasi pembelajaran, ada kelebihannya seperti menghemat ruang dan waktu serta memalsimalkannya. Semua mahasiswa merasakan adanya kelemahan dari digitalisasi pembelajaran, namun sudah ada solusi untuk mengatasi kesulitan tersebut, baik solusi yang dapat dilakukan oleh mahasiswa maupun dosen serta harapan untuk adanya pemerataan kemudahan 
akses pembelajaran. Adanya beragam dampak positif maupun negatif yang dirasakan mahasiswa. Karena tidak semua mahasiswa merasa mendapatkan fleksibilitas dan aksesibilitas yang baik, membuat adanya mahasiswa merasa pembelajaran dengan digitalisasi tidak efektif dan efisien. Tetapi sebagian besar sudah mersakaan keefektifan dan efiisiensi digitalisasi pembelajaran, terutama pada pembelajaran bahasa dan sastra Indonesia.

\section{REFERENCES}

[1] Asaniyah, "Pelestarian Informasi Koleksi Langka: Digitalisasi, Restorasi, Fumigasi." Buletin Perpustakaan No. 57 Mei 2017.

[2] Sari, Pusvyta. "Memotivasi belajar dengan menggunakan e-learning." Ummul Quro(2015).

[3] Atsani, KH lalu Gede Muhammad Zainuddin. "Transformasi Media Pembelajaran pada Masa Pandemi Covid-19." Al-Hikmah: Jurnal Studi Islam 1.1 (2020): 8293.VID-19.ndry, Luh Devi, et al. "Pembelajaran pada Masa Pandemi Covid-19." JTP-Jurnal Teknologi Pendidikan 22.1 (2020): 65-70.

[4] Salwa, Minchatus, and Nani Febrianti. “"Fleksibel dan Mudah" Pembelajaran Terkini Melalui Media Sosial.” (2020): 165-171.

[5] Trisnadewi, Komang, dan Ni Made Muliani. "Pembelajaran Daring di Masa Pandemi Covid- 19." Covid-19: Perspektif Pendidikan 35 (2020).

[6] Sari, Ayu Puspita Indah, dan Hastari Mayrita. "Variasi Pembelajaran Bahasan Indonesia Mahasiswa Universitas Bina Darma di Masa Pandemi.” Jurnal Ilmiah Bina Edukasi 13.2 (2020): 66-75.

[7] Susmiati, Eri. "Meningkatkan Motivasi Belajar Bahasa Indonesia Melalui Penerapan Model Discovery Learning dan Media Video Dalam Kondisi Pandemi Covid-19 bagi Siswa SMPN 2 Gangga.” Jurnal Paedagogy 7.3 (2020): 210-215.

[8] Kurniawan, Deddy. "Pembelajaran Bahasa Jerman di Kala Pandemi Covid-19: Fleksibilitas dan Aksesibilitas."(2020): 55-65.

[9] Setyorini, In. "Pandemi COVID-19 dan Online Learning: Apakah Berpengaruh Terhadap Proses Pembelajaran pada Kurikulum 13?." Journal of Industrial Engineering \& Management Research 1.1 (2020): 95-102.

[10] Napitupulu, Rodame Monitorir. "Dampak Pandemi Covid-19 Terhadap Kepuasan pembelajaran jarak jauh." Jurnal Inovasi Teknologi Pendidikan 7.1 (2020): 23-33. 